\title{
TAF1 Gene
}

National Cancer Institute

\section{Source}

National Cancer Institute. TAF1 Gene. NCI Thesaurus. Code C20421.

This gene is involved in transcriptional initiation, cell cycle progression and ubiquitination. 